\title{
Identifying the key factors influencing sustainable tourism in Bangladesh: A Quantitative Analysis
}

\author{
Nusrat Jahan \\ Assistant Professor, Dept. of Tourism \& Hospitality \\ Management, University of Dhaka \\ Dhaka, Bangladesh \\ E-mail: jahan_nusrat32@yahoo.com
}

\author{
Sabrina Rahman \\ Lecturer, Dept. of Tourism \& Hospitality Management, \\ American International University - Bangladesh (AIUB) \\ Dhaka, Bangladesh \\ E-mail: sabrina.rahman44@gmail.com
}

\begin{abstract}
The purpose of this research is to assess the potentials of Bangladesh in becoming one of the major sustainable tourism destinations of the world. Bangladesh - the land of unique natural beauties like the Sundarbans, Cox's Bazar, Sylhet, Hill tracts areas - is a country lying at the apex of the Bay of Bengal and sharing its borders with India and Myanmar. Sustainable tourism is about focusing and adapting principles developed to ensure the long-term growth of environmental, economic, and socio-cultural aspects of the tourism industry. In this research, the authors will collect data by conducting questionnaire survey on tourists, both domestic and international, who have visited any of the tourist destinations of Bangladesh at least once in their lifetime and by analyzing the survey data, authors will try to identify the salient factors that can make Bangladesh a sustainable tourism destination. The main focus of this research paper will be showing the impact of different variables of tourism industry in developing Bangladesh as a sustainable tourism destination. By identifying the factors, authors will then expand the scope of the research even further and will try to recommend possible solutions that can ensure the proper utilization of each of those factors in order to remove the hindrances from the way of making Bangladesh a sustainable tourism destination.
\end{abstract}

Key Words - Bangladesh, Sustainable Tourism Destination, Factors Crucial to Sustainable Tourism Development.

\section{INTRODUCTION}

Tourism, one of the world's largest economic sectors, has already taken some important steps in improving efficient utilization of energy and is increasingly using renewable energy technologies in its day to day operations. These steps are helping to create jobs, lift people out of poverty and help to protect the planet [1]. To keep pace with rest of the world, it is the high time for Bangladesh to take necessary initiatives that may accelerate in making Bangladesh a sustainable tourism destination and thus, can ensure long-term development of the tourism industry. By assessing the results and conclusions found in this research, it is hoped that it can be taken even further to find out approaches that would develop Bangladesh as a sustainable tourism destination.

\section{BACKGROUND TO THE RESEARCH}

Bangladesh has got huge potentials to develop in sustainable tourism sector but a very little number of research has been carried out on this topic. Despite of having plenty of tourist attractions that might be promoted as sustainable tourism destination; the concerned authority of tourism industry in Bangladesh is not taking enough actions to promote and maintain them and not adequate researches related to tourism industry are being conducted to identify the present obstacles and to find out the strategies to develop Bangladesh as one of the sustainable tourism destinations of the South-east Asia.

Thus, with this in mind, authors have focused on the perception of the tourists; both domestic and international; who have visited any of the tourist destinations of Bangladesh and have also tried to assess the factors affecting Bangladesh to be developed as a global sustainable tourism destination. This paper will facilitate the way of making Bangladesh as a sustainable tourism destination through identifying the crucial variables that may have significant impact on the sustainable tourism sector of Bangladesh.

\section{OBJECTIVES OF THE RESEARCH}

\section{A. Broad Objective:}

To find out the perception of domestic and international tourists regarding the potential of Bangladesh to become a sustainable tourism destination and to identify the factors that are crucial to make Bangladesh as one of the sustainable tourism destinations of the world.

\section{B. Specific Objectives:}

- To identify the potentialities of Bangladesh in becoming a sustainable tourism destination from the point of view of its tourists.

- To discover the actual conditions of the services offered to the tourists during their visit to different destinations of Bangladesh.

- To point out the factors that play vital role in making Bangladesh a sustainable tourism destination.

- To recognize the level of community involvement in different tourist destinations of Bangladesh.

- To find out the level of consciousness of tourists visiting Bangladesh about conducting tourism related activities in an environment-friendly manner. 
- To suggest the policymakers and other stakeholders of the tourism industry with some ideas to promote Bangladesh as a sustainable tourism destination.

\section{LITERATURE REVIEW}

\section{A. Tourism Industry: the Present Scenario:}

UNWTO [2] defines tourists as people "traveling to and staying in places outside their usual environment for not more than one consecutive year for leisure, business and other purposes".

To date, tourism is a major source of income for many countries, and affects the economy of both the source and host countries, in some cases it is of vital importance [3]. Many authors $[4,5,6]$ define domestic tourism as 'people's visiting activities to different destinations within the geographical boundary of their own country of residence'.

Tourism suffered as a result of a strong economic slowdown of the late-2000s recession, between the second half of 2008 and the end of 2009, and the outbreak of the H1N1 influenza virus [2]. It then slowly recovered, with international tourist arrivals surpassed the milestone 1 billion tourists globally for first time in history in 2012 [1].

However, evidence suggests that tourism, as a global phenomenon shows no signs of substantially abating in the long term. It has been suggested that travel is necessary in order to maintain relationships, as social life is increasingly networked and conducted at a distance [7]. For many people vacations and travel are increasingly being viewed as a necessity rather than a luxury and this is reflected in tourist numbers recovering some $6.6 \%$ globally over 2009 , with growth up to $8 \%$ in emerging economies [8].

Scholars assert that tourism is in a form which can maintain its variability in an area for an infinite period of time [9]. It has emerged from being a relatively small-scale activity into a global economic phenomenon from the 1960s onward [10].

\section{B. Sustainable Tourism}

Butler [11] defines sustainable tourism is defined as tourism that respects both local people and the traveler, cultural heritage and the environment. It seeks to provide people with an exciting and educational holiday that is also of benefit to the people of the host country. Sustainable tourism also seeks deeper involvement of locals, which provide local people an opportunity and make their living [1]. Achieving sustainable tourism is a continuous process and it requires constant monitoring of impacts, introducing the necessary preventive and/or corrective measures whenever necessary [12].

However, sustainable tourism development meets the needs of the present tourists and host regions while protecting and enhancing the opportunity for the future [10]. Although tourism has proved effective as a vehicle for economic growth, the fundamental principles of sustainable development - including equity, holistic planning and sustainability - cannot be easily transposed onto the sector [6].
Socially, tourism is credited for its potential impact on employment; income redistribution and poverty alleviation; contribution to native craft revival, festivals and traditions; and improvements to the physical and social infrastructure, enhancing overall health and social welfare [10]. Also, sustainability principles refer to the environmental, economic, and socio-cultural aspects of tourism development, and a suitable balance must be established between these three dimensions to guarantee its long-term sustainability [12]. Thus, sustainable tourism should:

1. Make optimal use of environmental resources that constitute a key element in tourism development, maintaining essential ecological processes and helping to conserve natural heritage and biodiversity.

2. Respect the socio-cultural authenticity of host communities, conserve their built and living cultural heritage and traditional values, and contribute to inter-cultural understanding and tolerance.

3. Ensure viable, long-term economic operations, providing socio-economic benefits to all stakeholders that are fairly distributed, including stable employment and income earning opportunities and social services to host communities, and contributing to poverty alleviation.

\section{Bangladesh: As a destination}

Bangladesh as a developing country in South Asia with an area of 147,570 square kilometers and a population of 140 million [13]. It is bordered on the west, north, and east by India, on the southeast by Myanmar, and the Bay of Bengal to the south [14]. Though it is a small country, the total contribution of the travel \& tourism sector of Bangladesh to GDP was BDT460.3bn (4.4\% of GDP) in 2013, and is predicted to rise by $6.5 \%$ pa to BDT935.5bn (4.7\% of GDP) in 2024 [15].

Unfortunately, despite of having the longest sea beach of the world at Coxes Bazar, the largest mangrove forest, the Sundarbans, attractive hilly areas in Sylhet and Chittagong Hill Tracts, Bangladesh could not attract sufficient number of foreign tourists in previous years [3]. In Bangladesh, insufficient infrastructural development at various tourist spots, lack of proper facilities for the tourists, scarcity of skilled and professional tour service providers and poor promotional programs are responsible for the lower response from the foreign tourists [3]. Therefore, the target customers are not getting attracted properly and thus the tourism sector in Bangladesh is not flourishing as it was expected to be.

The performance of a place as tourist destination and satisfaction of visitors are of paramount importance to the destination competitiveness since the pleasantness of the experience is more likely to influence visitors' future behavior [16]. According to a research conducted by Katalyst [17] in 2010 , the constraints for which the sector is struggling to keep up with the growth pace of other Asian countries are: absence of effective policy and planning, inadequate development of destination's infrastructures, environmental degradation, inadequate modern tourist facilities, lack of access to skilled manpower and poor promotional and awareness-creating 
programs are the major impediments hindering the growth of this sector.

Despite all of these impediments, Bangladesh Parjatan Corporation [9] has estimated that the annual growth of the inbound tourists in Bangladesh over the last 8 years has been around $9 \%$ on an average. Moreover, Bangladesh is engaged in a continuous endeavor to integrate her ecotourism resources through planning, management and appropriate use, based on the following principles: (i) optimum multiple uses of the resources; (ii) maximum sustainable use; and (iii) conservation and development of natural resources [18].

\section{METHODOLOGY}

\section{A. Scope of the Study}

This research paper will try to cover the tourists who have visited at least one tourist destinations of Bangladesh (both domestic \& international). The scope of the information will be limited within the opinions of its respondents.

\section{B. Research Design}

In line with the research purposes of this study, a questionnaire based survey was administrated among the target population. Since this research was focused on the factors influencing sustainable tourism, the survey was among both local and foreign tourists.

The survey was conducted on 329 respondents residing temporarily or permanently in any of the seven divisions of Bangladesh. Among them 150 were from Dhaka division, 55 were from Chittagong division, 31 were from Rajshahi division, 27 were from Khulna division, 26 were from Barisal division, 24 were from Sylhet division and 16 were from Rangpur division. This research has covered a wide array of professions like: students, housewives, employees working any private company, government employees, businessmen etc.

\section{Data Collection \& Analysis}

This research is done on the basis of descriptive method of research. The term descriptive research refers to the type of research question, design, and data analysis along with descriptive statistics, while inferential statistics try to determine cause, solution and effect [19]. The respondants were asked to fill questionnaire and rate the importance of the items based on five-point Likert scale.

Primary data were being collected through the questionnaire that has been prepared for collecting the responses of tourists who have visited Bangladesh. With this data, the authors would run index analysis to find out the mean value of each variable and thus, to determine the positive and negative impact of each of them to make Bangladesh into a sustainable tourism destination. The authors would also conduct factor analysis to categorize the variables into factors that would describe the groups of important variables which are critical to establish Bangladesh as a sustainable tourism destination.
Moreover, secondary data were being collected from different e-journals, paper journals and other available published sustainable tourism papers/magazines of Bangladesh and other countries. The selection of the sampling units was left primarily to the interviewer.

\section{Limitations}

There are a few limitations of this study which might hamper its targeted results.

One of them is lack of demographic variability among respondents due to insufficient fund for conducting the research.

The data from international tourists were collected by going to the hotels in which they had been staying and due to financial and time constraints, it was limited to the tourists staying in hotels located in Dhaka only. So, the expected ratio between domestic and international tourists could not be achieved. This lack of variability in respondents' demographic background may, in turn, restrict the survey results.

\section{ANALYSIS OF RESPONDENTS' DEMOGRAPHIC BACKGROUND}

4 demographic variables in were being given in the questionnaire to find out different demographic features; such as- age, gender, purpose of travel and occupation of the survey respondents. This demographic analysis has helped us to find out the proportion of male and female tourists of different age and profession and the reason for which they visit to any tourist destination in Bangladesh.

The authors have collected data from 54 international tourists who had been living in different hotels of Dhaka city during the time of our survey. The other 275 respondents of our survey were local people from all seven administrative divisions of Bangladesh. The following tables show the categorization the respondents on their gender, age, occupation and purpose of travel:

TABLE I. GENDER OF THE RESPONDENTS

\begin{tabular}{|c|c|}
\hline \multicolumn{2}{|c|}{ Gender } \\
\hline Gender & No. of respondents \\
\hline Male & 224 \\
\hline Female & 105 \\
\hline
\end{tabular}

TABLE II. AGE OF THE RESPONDENTS

\begin{tabular}{|c|c|}
\hline \multicolumn{2}{|c|}{ Age } \\
\hline Age classes & No. of respondents \\
\hline $18-29$ & 91 \\
\hline $30-39$ & 72 \\
\hline $40-49$ & 63 \\
\hline $50-59$ & 51 \\
\hline $60-69$ & 40 \\
\hline $70+$ & 12 \\
\hline
\end{tabular}


TABLE III. OCCUPATION OF THE RESPONDENTS

\begin{tabular}{|c|c|}
\hline \multicolumn{2}{|c|}{ Occupation } \\
\hline Categories & No. of respondents \\
\hline Professional & 28 \\
\hline Student & 55 \\
\hline Management & 34 \\
\hline Housewife & 23 \\
\hline Company Employee & 77 \\
\hline Govt. Employee & 60 \\
\hline Private Business & 46 \\
\hline Other & 6 \\
\hline
\end{tabular}

TABLE IV. PURPOSE OF TRAVEL

\begin{tabular}{|c|c|}
\hline \multicolumn{2}{|c|}{ Purpose of Travel } \\
\hline Purpose & No. of respondents \\
\hline Pleasure & 113 \\
\hline Family & 81 \\
\hline Business & 107 \\
\hline Other & 28 \\
\hline
\end{tabular}

VII. ANALysis Of THE SURVEY DATA

\section{A. Reliability of Data}

The reliability of data was verified using both Alpha and Split Half Technique. The data was found to be achieving 0.77 Cronbach's Alpha value. A Cronbach's Alpha of a study (0.70) is considered to be reliable [19].

\section{B. Index Analysis of Survey Data}

25 variables were selected to explain the potentiality of Bangladesh to be a major sustainable tourism destination. The Index Value (Mean of the 25 simple variables of all the samples) was 0.6007 . However, the mean of the Last Variable, named 'Bangladesh has the potential to be a major tourist destination' was the direct measurement of Future Potentiality as a sustainable tourism destination of Bangladesh, was found to be 0.6000 .

A similarity test with the Average Potential and the Factor question revealed that the average value is $99.88 \%$ similar with the responded value $(* * *$ Similarity here refers to how the indexed and the future potentiality level of the sample are mathematically close).

According to the index analysis, the mean values for each of the 25 variables explaining the level of future potentiality of Bangladesh to be a sustainable tourism destination are given in the table below:

TABLE V. DATA FROM INDEX ANALYSIS

\begin{tabular}{|c|c|}
\hline Variables & Mean \\
\hline Accommodation facility is good enough & .7455 \\
\hline
\end{tabular}

\begin{tabular}{|c|c|}
\hline Variables & Mean \\
\hline Staying in high standard hotel is fine & -.1909 \\
\hline Quality food \& beverage of the restaurants & .9273 \\
\hline Take local food/drinks & .8636 \\
\hline Transportation system is good & .7091 \\
\hline $\begin{array}{l}\text { The comfort of journey for the most while } \\
\text { choosing transportation }\end{array}$ & 1.0545 \\
\hline $\begin{array}{l}\text { The quality of services should be there, no } \\
\text { matter how much money they cost }\end{array}$ & .2727 \\
\hline $\begin{array}{l}\text { Tourists' are informed about the cultural, social } \\
\text { norms and economic conditions of people }\end{array}$ & .4273 \\
\hline $\begin{array}{l}\text { Businesses are favored with willingness to } \\
\text { conserve cultural heritage and traditional values }\end{array}$ & 1.0545 \\
\hline $\begin{array}{l}\text { Consumption of local goods to support local } \\
\text { families }\end{array}$ & 1.0273 \\
\hline $\begin{array}{l}\text { Avoid littering the tourist spots with waste } \\
\text { materials }\end{array}$ & 1.2364 \\
\hline $\begin{array}{l}\text { Taking services from environmentally } \\
\text { responsible businesses }\end{array}$ & .9545 \\
\hline Buy things which are not harmful to nature & 1.3091 \\
\hline Tourists' use non-renewable resources carefully & .9909 \\
\hline Proper maintenance of tourist spots & -.3455 \\
\hline $\begin{array}{l}\text { Concerned authority is enough cautious natural } \\
\text { degradation of destinations }\end{array}$ & 1.3273 \\
\hline $\begin{array}{l}\text { ST will improve economic condition of local } \\
\text { people }\end{array}$ & 1.4091 \\
\hline $\begin{array}{l}\text { ST will make positive impact on natural and } \\
\text { cultural heritage }\end{array}$ & 1.3545 \\
\hline $\begin{array}{l}\text { Local people are conscious about protecting } \\
\text { tourist destination and environment }\end{array}$ & -.1909 \\
\hline Local people are involved in tourism activities & -.0455 \\
\hline $\begin{array}{l}\text { Tourists are conscious about natural, cultural } \\
\text { heritages and sites }\end{array}$ & -.2545 \\
\hline $\begin{array}{l}\text { Service providers are sensitive to environmental } \\
\text { pollution and natural degradation }\end{array}$ & -.1818 \\
\hline ST will create more employment for local people & 1.2091 \\
\hline Local people are friendly & -.4545 \\
\hline $\begin{array}{l}\text { Tourists tend to take responsibilities for their } \\
\text { actions }\end{array}$ & -.1909 \\
\hline \multicolumn{2}{|l|}{ Valid N (list wise) } \\
\hline Index Value $=($ total mean $/ 25)=$ & .6007 \\
\hline
\end{tabular}

\section{Factor Analysis of Survey Data}

KMO value for the research was 0.501 . This indicates that the number of data collected under the research is enough to run the factor analysis [19]. From the Factor Analysis, it was interpreted that Initial Eigen values can explain $70.959 \%$ of the variance can be described by 8 Factors. After 300 Varimax Rotations, 8 Factors were found. The 8 Factors are presented below in the table 8 which describes the new grouping of important variables which are critical to establish Bangladesh as a sustainable tourism destination.

TABLE VI. DATA FROM FACTOR ANALYSIS

\begin{tabular}{|l|lr|c|}
\hline Factor & \multicolumn{2}{|c|}{ Variable (factor loading) } & $\begin{array}{c}\text { Variance Explained } \\
\text { (total 70.959\%) }\end{array}$ \\
\hline Factor 1: & $\begin{array}{l}\text { Local } \\
\text { Consumption }\end{array}$ & Food/Beverage \\
Purchasing & Sustainable & Service & \\
\hline
\end{tabular}




\begin{tabular}{|c|c|c|}
\hline Factor & Variable (factor loading) & $\begin{array}{c}\text { Variance Explained } \\
\text { (total } 70.959 \%)\end{array}$ \\
\hline $\begin{array}{l}\text { Preference } \\
(17.582 \%)\end{array}$ & $\begin{array}{l}\text { Preference }(.768) \text {, Cultural } \\
\text { heritage } \\
\text { Preference }(.748) \text {, Avoiding } \\
\text { Harmful Objects }(.748) \text {. }\end{array}$ & \\
\hline $\begin{array}{l}\text { Factor 2: } \\
\text { Condition of } \\
\text { Major } \\
\text { Supporting } \\
\text { Services } \\
(12.414 \%)\end{array}$ & \begin{tabular}{llr} 
Good & \multicolumn{2}{c}{ accommodation } \\
facility & $(0.809)$, & service \\
providers & sensitivity & toward \\
pollution & $(0.736)$, & good \\
transportation & facility \\
$(0.636)$ &
\end{tabular} & $12.414 \%$ \\
\hline $\begin{array}{l}\text { Factor 3: } \\
\text { Quality of } \\
\text { Service } \\
\text { Demanded } \\
(10.494 \%)\end{array}$ & $\begin{array}{l}\text { Preferring high standard } \\
\text { hotels }(0.795), \text { preferring } \\
\text { only high quality services } \\
(0.730) \text {, preferring quality } \\
\text { food and beverages }(0.682) \\
\text { and preferring comfortable } \\
\text { transportation }(0.630)\end{array}$ & $10.494 \%$ \\
\hline $\begin{array}{l}\text { Factor } 4: \\
\text { Impact of } \\
\text { Sustainable } \\
\text { Tourism } \\
(8.355 \%)\end{array}$ & $\begin{array}{l}\text { positive impact on heritages } \\
(0.801) \text {, improving economic } \\
\text { condition of local people } \\
(0.752) \text {, create local peoples' } \\
\text { employment opportunities } \\
(0.638) \text { and well-informed } \\
\text { tourists about the actual } \\
\text { condition of local people } \\
(0.439)\end{array}$ & $8.355 \%$ \\
\hline $\begin{array}{l}\text { Factor 5: } \\
\text { Involvement } \\
\text { of Locals and } \\
\text { Concerned } \\
\text { Authority }\end{array}$ & $\begin{array}{l}\text { Concerned authorities' } \\
\text { cautiousness about natural } \\
\text { degradation of destinations } \\
(0.718) \text {, friendly local people } \\
(0.670) \text { and involved local } \\
\text { people }(0.665)\end{array}$ & $7.027 \%$ \\
\hline $\begin{array}{l}\text { Factor } 6 \text { : } \\
\text { Level of } \\
\text { Responsibility }\end{array}$ & $\begin{array}{l}\text { having local food/drinks } \\
(0.717), \text { environmentally } \\
\text { protective and conscious } \\
\text { local people }(0.711) \text {, } \\
\text { responsible tourists }(0.511)\end{array}$ & $5.460 \%$ \\
\hline $\begin{array}{l}\text { Factor 7: } \\
\text { Natural } \\
\text { Resources and } \\
\text { Environment }\end{array}$ & $\begin{array}{l}\text { Careful use of non- } \\
\text { renewable resources }(0.841) \text {, } \\
\text { proper maintenance of } \\
\text { tourist destinations }(0.743)\end{array}$ & $5.182 \%$ \\
\hline $\begin{array}{l}\text { Factor 8: } \\
\text { Tourists' } \\
\text { Knowledge } \\
\text { and } \\
\text { Cautiousness }\end{array}$ & $\begin{array}{l}\text { Tourists' consciousness } \\
\text { about natural and cultural } \\
\text { heritages }(0.776) \text {, conscious } \\
\text { tourists about not littering } \\
\text { tourist spots }(0.437)\end{array}$ & $4.444 \%$ \\
\hline
\end{tabular}

\section{FINDINGS FROM SURVEY DATA}

\section{A. Findings from Index Analysis}

According to the index analysis of this research, we have found the mean values (based on the opinions of the tourists surveyed) for each of the 25 variables explaining the potentiality of Bangladesh to be a sustainable tourism destination. Based on their mean (absolute values), we have categorized those variables into low $(>0.67)$, medium $(0.68$ 1.33) and high (1.34-1.99) levels; either positive or negative; to understand their level of impact on the tourism industry of Bangladesh.

The policymakers of tourism industry should focus on the variables that have got medium and high level impact on the tourism industry and should take necessary steps to develop those variables as they have been found more important from the tourists' point of view in order to make Bangladesh as a sustainable tourism destination.

TABLE VII. FINDINGS FROM INDEX ANALYSIS

\begin{tabular}{|c|c|c|}
\hline $\begin{array}{c}\text { Mean } \\
\text { (Absolute } \\
\text { Value) }\end{array}$ & Positive & Negative \\
\hline Low $(<0.67)$ & $\begin{array}{l}\text { preferring only high } \\
\text { quality services, well- } \\
\text { informed tourists about } \\
\text { the actual condition of } \\
\text { local people }\end{array}$ & $\begin{array}{l}\text { Preferring high standard } \\
\text { hotels, } \\
\text { maintenance of tourist } \\
\text { spots, environmentally } \\
\text { protective and conscious } \\
\text { local people, involved } \\
\text { local people, Tourists' } \\
\text { consciousness about } \\
\text { natural and cultural } \\
\text { heritages, } \\
\text { providers cautiousness } \\
\text { about natural degradation } \\
\text { of destinations, friendly } \\
\text { local people, responsible } \\
\text { tourists }\end{array}$ \\
\hline $\begin{array}{l}\text { Medium (0.68- } \\
1.33)\end{array}$ & 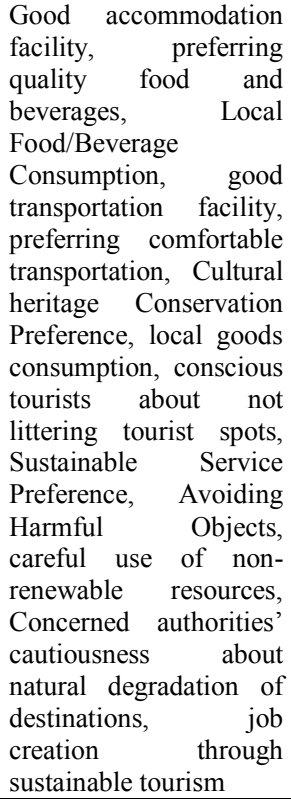 & \\
\hline $\begin{array}{l}\text { High (1.34- } \\
1.99)\end{array}$ & $\begin{array}{l}\text { Improved economy for } \\
\text { local people through } \\
\text { sustainable tourism, } \\
\text { natural and cultural } \\
\text { conservation through } \\
\text { sustainable tourism }\end{array}$ & \\
\hline
\end{tabular}

\section{B. Findings from Factor Analysis}

8 factors have been found from the factor analysis of the data collected by the survey. Among those 8 factors, top 3 factors can be announced as the most important factors that influence the future potential of Bangladesh as a Major sustainable tourism destination. Those 3 factors explain $40.517 \%$ of the variance and they are- purchasing preference (17.582\%), condition of major supporting services (12.414\%) and quality of service demanded (10.494\%). Thus, according to the findings from factor analysis, in order to develop Bangladesh as a sustainable tourism destination, the policymakers have to undertake strategies that foster 
environmentally friendly businesses and encourage local community to develop products and services with hurting the nature, to develop the accommodation, transportations and other supporting services of the tourism industry and to implement rules in order to maintain the desired quality of those supporting services.

\section{CONCLUSION}

From conducted research, many important variables influencing the future potential of Bangladesh to be a sustainable tourism destination have been found. Though, this country has many natural sites and cultural heritages; due to the absence of proper maintenance and appropriate policies, those heritages and sites are losing their beauty and attraction day by day.

The taste, preference and demand of tourists are changing by time. At present, there are plenty of tourists who want to spend their leisure time in nature without any negative impact on the destination and Bangladesh should start positioning themselves as a sustainable tourism spot in order to attract this rapidly increasing market segment- the responsible tourists.

According to the conducted research, more than half of the respondents think that Bangladesh has great potentials to be one of the major sustainable tourism destinations in the world. It is also clear that there are numerous ways for improvement to achieve greater success in establishing Bangladesh as a sustainable tourism destination and to promote sustainable tourism in Bangladesh to attract more and more nature loving tourists. In this paper, the authors have tried to find the vital variables that influence the growth of sustainable tourism in Bangladesh. These variables have to be further analyzed and enriched to find out ways in order to establish Bangladesh as a major sustainable tourism destination.

\section{A. Recommendations for Further Research:}

This survey can be analyzed further and researchers can expand the scope of this research in an advanced stage by conducting regression analysis with the variables found in the factor analysis of this research and it will be useful to the stakeholders or the service-providing organizations tourism industry; like: Ministry of Civil Aviation \& Tourism of Bangladesh, Bangladesh Parjatan Corporation (BPC), Bangladesh Tourism Board (BTB), Tour Operators' Association of Bangladesh (TOAB), Association of Travel Agents of Bangladesh (ATAB) and Pacific Asian Travel Association (PATA). Moreover, individual organizations working for the development of tourism industry of Bangladesh can work further on this research paper as it will assist them to make action-plans and strategies that will ensure the long-term growth of the tourism industry and will pave the way for making Bangladesh as a sustainable tourism destination.

\section{REFERENCES}

[1] UNWTO Annual Report. (2013). United Nations World Tourism Organization [Online]. Available: http://cf.cdn.unwto.org/sites/all/files/ pdf/unwto_annual_report_2013_0.pdf

[2] UNWTO World Tourism Barometer, World Tourism Organization, 2010 .

[3] C. Cooper et al., Tourism Principle and Practice, 4th ed. Essex: Pearson, 2008.

[4] J. Jafari, (1986), "Overview on Domestic Tourism", in Annals of Tourism Research [Online]. Available: http://ac.els-cdn.com/016073 8386900332/1-s2.0-0160738386900332-main.pdf? tid=bc892d463a041 e3bd8100000aab0f01\&acdnat=1382327956_a46b8672865f440614edb1 $32 \mathrm{f} 2507 \mathrm{f} 2$ ),

[5] J. Jafari, Encyclopedia of Tourism, 1st ed, London: Routledge, 2002.

[6] R. Sharpley and D. J. Telfer, "Tourism and Development-Concepts and Issues", Clevedon: Channel View Publications, 2002.

[7] J. Urry, "Social Networks, Travel and Talk", in British Journal of Sociology, 54 (2): 155-175, 2003.

[8] UNWTO Tourism Highlights, United Nations World Tourism Organization, 2012.

[9] Bagladesh Parjatan Corporation. (2009). BPC Tourism Statistics. [Online]. Available: http://www.parjatan.gov.bd/ tourism2009.php

[10] Tourism and sustainable development - Report of the Secretary General, United Nations, 1999.

[11] R. Butler, "Tourism, environment, and sustainable development, Environmental Conservation”, 1991.

[12] "Making tourism more sustainable - a guide for policy makers", United Nations Environment Programme and United Nations World Tourism Organization, 2005.

[13] S. Baloglu et al., "The relationship between destination performance, overall satisfaction, and behavioral intention for distinct segment", in Journal of Quality Assurance in Hospitality \& Tourism, 17 (1), 149-165 [Online]. Available: http://www.haworthpress.com/web/JQAHT, 2003.

[14] S. M. N. Islam, "Tourism Marketing in Developing countries: a study of Bangladesh: Hospitality and Tourism Management", University of Strathclyde, Glasgow, 2013.

[15] Travel \& Tourism Economic Impact. (2014). World Travel and Tourism Council [Online]. Available:http://www.wttc.org//media /files/reports/ economic\%20impact\%20research/regional\%0reports/ world2014.pdf

[16] UNWTO technical manual: Collection of Tourism Expenditure Statistics, World Tourism Organization, Madrid, Spain, (1995).

[17] Katalyst. (2010). "Views on Tourism -focus on Bangladeshi tourism" [Online]. Available: http://www.viewsontourism.info/2010/katalystfocus-on-bangladeshi-tourism/

[18] Euromonitor International. (2009, October). Travel and Tourism in Bangladesh. [Online]. Available: http://www.euromonitor.com

[19] N. K. Malhotra, Marketing Research: An Applied Orientation, 6th Ed, New Jersey: Pearson, 2010. 